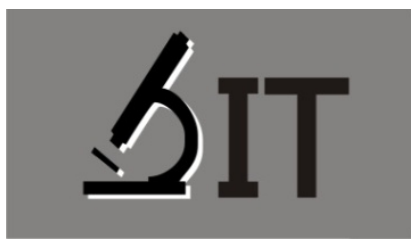

p-ISSN : 2597-8977

e-ISSN : 2597-8985

Sitti Rahma Yunus

Universitas Negeri Makassar

Sudarto

Universitas Negeri Makassar

Risman Adrianto

Universitas Negeri Makassar
JIT 3 (1) (2019) 12-19

JURNAL IPA TERPADU

http://ojs.unm.ac.id/index.php/ipaterpadu

\section{PENGARUH METODE PEMBELAJARAN BERMAIN PERAN TERHADAP HASIL BELAJAR PESERTA DIDIK KELAS VII SMP NEGERI 24 BULUKUMBA（STUDI PADA MATERI POKOK PENCEMARAN LINGKUNGAN)}

Abstrak: Penelitian ini bertujuan untuk mengetahui ; (1) Hasil belajar peserta didik kelas VII SMP Negeri 24 Bulukumba pada materi pokok pencemaran lingkungan dengan menggunakan metode pembelajaran bermain peran. (2) Hasil belajar peserta didik kelas VII SMP Negeri 24 Bulukumba pada materi pokok pencemaran lingkungan dengan menggunakan metode ceramah. (3) Ada tidaknya pengaruh positif metode pembelajaran bermain peran terhadap hasil belajar peserta didik SMP Negeri 24 Bulukunba pada materi pokok pencemaran lingkungan. Metode penelitian yang digunakan adalah metode Quasi-eksperiment dengan menggunakan Non-Equivalent Posttest-Only Control Group Design. Populasi penelitian adalah peserta didik kelas VII SMP Negeri 24 Bulukumba semester genap tahun pelajaran 2016/2017 yang terdiri dari lima kelas, sedangkan sampel penelitian sebanyak dua kelas yaitu kelas VII.1 sebagai kelas eksperimen dan kelas VII.4 sebagai kelas kontrol, ditentukan dengan cara random sampling. Instrumen untuk mendapatkan data hasil belajar berupa soal pilihan ganda yang berjumlah 20 item yang sebelumnya telah dilakukan uji validitas, diberikan di akhir penelitian. Untuk mengetahui ada tidaknya pengaruh metode pembelajaran bermain peran terhadap hasil belajar, data yang diperoleh dilakukan analisis statistik deskriptif dan statistik inferensial untuk kedua kelas. Hasil analisis data deskriptif diperoleh untuk kelas eksperimen nilai rata-rata sebesar 75,50 dan kelas kontrol rata-rata sebesar 68,16, masuk pada kategori tinggi. Berdasarkan hasil uji hipotesis diperoleh bahwa Ho ditolak dan $\mathrm{Ha}$ diterima yang artinya ada pengaruh positif metode pembelajaran bermain peran terhadap hasil belajar peserta didik SMP Negeri 24 Bulukumba pada materi pokok pencemaran lingkungan.

Kata Kunci: Metode pembelajaran bermain peran, Hasil belajar

Abstract: This research aim to know ; (1) learning outcomes of students of The First Grade of SMPN 24 Bulukumba in environmental pollution subject by using role playing learning method. (2) learning outcomes of students of The First Grade of SMPN 24 Bulukumba in environmental pollution by using speech method. (3) The positive effect of role playing learning method to the learning outcomes of students of The First Grade of SMPN 24 Bulukumba in over population and environmental pollution subject. The type of this research used is Quasi-experiment by using research desaign Non EquivalentPosttest-Only Control Group Design. Population of 
this research is students of The First Grade of SMPN 24 Bulukumba even semester in 2017/2018 that consist of five classes. The sample of this research are two classes those are VII.1 as experiment class and VII.4 as control class that is chosen in random sampling. The instrument of research is multiple choice those are 20 items that is done validity test before. The way in collecting the data that is done in this research is the data of studying result taken from post-test both of the classes. To know the influence of role playing learning method that is researched can be seen from the result of statistic descriptive analysis and statistic inferensial for both of classes. Based on the result of data analysis and experiment classes discussion acquire average value 75,50 in high category and class control acquire average value 68,16 in medium category. The result of hypotheses acquire that Ho rejected and $\mathrm{H}_{1}$ accepted means that there is the possitive influence of role playing learning method to the learning outcomes of the students of SMPN 24 Bulukumba in environmental pollution.

Keywords: Role playing learning method, learning outcomes

\section{PENDAHULUAN}

Dunia pendidikan terus mengalami perubahan yang signifikan sehingga mengubah pola pikir peserta didik, dari pola pikir yang awam menuju pola pikir yang lebih maju. Hal serupa juga berlaku pada kemajuan pendidikan di Indonesia. Banyak pakar-pakar pendidikan yang mengkritisi teori pendidikan dengan maksud untuk mencapai tujuan pendidikan yang sesungguhnya. Menurut Sukmadinata (2007) Pendidikan berfungsi membantu peserta didik dalam mengembangkan dirinya, yaitu pengembangan semua potensi, kecakapan, serta karakteristik pribadinya kearah yang positif, baik bagi dirinya maupun lingkungannya.

Seiring dengan kemajuan pendidikan, pemerintah melakukan upaya-upaya peningkatan pendidikan di Indonesia.Salah satu upaya yang dilakukan yaitu peningkatan mutu tenaga pendidik serta metode yang digunakan dalam pembelajaran pendidikan. Dan metode pembelajaran merupakan langkah-langkah operasional dari strategi pembelajaran yang dipilih untuk mencapai tujuan pembelajaran. Dengan demikian, metode pembelajaran merupakan langkah penting dalam proses pembelajaran sehingga wajar jika metode pembelajaran berpengaruh dalam proses pembelajaran sesuai dengan kemajuan ilmu pengetahuan.

Ilmu Pengetahuan Alam (IPA) merupakan ilmu pengetahuan yang mempelajari tentang gejala- gejala alam yang meliputi makhluk hidup dan makhluk tak hidup. Ilmu Pengetahuan Alam adalah program untuk mengembangkan pengetahuan, keterampilan, sikap dan nilai ilmiah pada peserta didik hingga mencintai dan menghargai kebesaran Tuhan Yang Maha Esa. Ilmu Pengetahuan Alam diharapkan dapat menjadi wahana bagi peserta didik untuk mempelajari diri sendiri dan alam sekitar, serta perbaikan dan pengembangan untuk menerapkannya dalam kehidupan sehari-hari

IPA di sekolah menengah pertama merupakan mata pelajaran yang memadukan antara konsep fisika, kimia, dan biologi. Salah satu tujuan utama Pembelajaran IPA adalah dapat meningkatkan minat dan motivasi serta efisiensi dan efektiitas pembelajaran. Untuk mencapai tujuan di atas, guru harus menggunakan berbagai macam media pembelajaran, metode pembelajaran, dan strategi pembelajaran untuk meningkatkan hasil belajar peserta didik. Karena, pada masa anak-anak adalah masa dimana tak terpisahkan dengan kegiatan bermain. Bermain merupakan kegiatan yang disenangi oleh anak-anak seperti SMP (Sekolah Menengah Pertama). Di 
usia ini anak-anak lebih banyak meluangkan waktu untuk bermain dibandingkan belajar bahkan sulit untuk diajak belajar.

Berdasarkan hasil observasi yang telah dilakukan di SMP Negeri 24 Bulukumba diperoleh informasi bahwa hasil belajar peserta didik pada pembelajaran IPA masih rendah. Informasi lebih lanjut berdasarkan observasi bahwa peserta didik kurang antusias dalam pembelajaran, hal ini disebutkan bahwa peserta didik kurang berpartisipasi aktif dalam pembelajaran sehingga hasil belajar peserta didik rendah. Metode yang biasa dipakai guru pada saat pembelajaran IPA, guru masih menggunakan metode pembelajaran yang masih satu arah yaitu ceramah. Kegiatan diskusi jarang dilaksanakan dalam pembelajaran. Pembelajaran satu arah tersebut berpusat pada guru (teacher centered learning) dan juga belum ada keterpaduan. Pada penggunaan metode pembelajaran yang masih satu arah tersebut, peserta didik hanya menerima apa yang diinformasikan oleh guru, guru bersifat informatif bagi peserta didik. Hal ini mengakibatkan pencapaian hasil belajar peserta didik diperoleh dari pemahaman peserta didik dalam mengerjakan soal ulangan harian. Hasil belajar ini tergolong masih rendah yakni sebanyak $55 \%$ dari 100 peserta didik belum mencapai Kriteria Ketuntasan Minimal (KKM) yang telah ditetapkan sekolah yaitu 70 dengan rata-rata nilai yang belum tuntas sebesar 61 .

Bertolak dari hal tersebut di atas, maka diperlukan adanya suatu variasi pembelajaran yang menarik, inovatif dan lebih mengaktifkan peserta didik. Metode berperan sebagai alat motivasi ekstrinsik, karena metode berfungsi sebagai perangsang dari luar yang dapat membangkitkan hasil belajar peserta didik. Salah satu metode pembelajaran yang dapat mengaktifkan peserta didik yaitu metode pembelajaran bermain peran. Metode pembelajaran ini memberikan kesempatan setiap anggotanya untuk memperoleh pengalaman belajar, sehingga memperoleh peserta didik dalam membangun sendiri pengetahuannya.

Metode bermain peran sendiri merupakan metode pembelajaran yang tidak dapat diterapkan pada semua materi pelajaran, karena metode ini berisi tentang pemeranan suatu peristiwa, sehingga hanya materi- materi yang mempunyai ciri-ciri adanya suatu peristiwa, suatu proses atau mekanisme, misalnya pencemaran lingkungan, dipilih materi tersebut berdasarkan data nilai ulangan harian siswa serta karakteristik materi yang cocok. Pada pelaksanaan metode ini, setelah pemeranan selesai dilaksanakan kemudian dilanjutkan dengan diskusi informasi dalam kelompok- kelompok kecil.

Menurut Piaget dalam Siska (2011), awal main peran dapat menjadi bukti perilaku anak. la menyatakan bahwa main peran ditandai oleh penerapan cerita pada objek dan mengulang perilaku menyenangkan yang diingatnya. Pelaksanaan bermain peran ini disertai dengan apron (karton bertuliskan nama peran) yang dikalungkan pada peserta didik sesuai perannya. Tujuannya adalah untuk memperjelas peran seorang peserta didik. Penggunaan kartu peran sebagai salah satu media pembantu dalam belajar sangat menunjang, apalagi diperankan sehingga berkesan hidup, bergerak serta dapat diamati langsung, sehingga membantu peserta didik dalam menganalogikan dengan benda pada peristiwa yang diperankan. Kesan yang didapatkan peserta didik dengan menggunakan metode pembelajaran bermain peran pada materi yang dipelajari akan lebih kuat, diharapkan dapat memotivasi peserta didik dan meningkatkan minat peserta didik, yang akhirnya dapat meningkatkan hasil belajar peserta didik.

Sesuai dengan penelitian yang telah dilakukan Selviana (2013), dengan judul Pengaruh metode bermain peran terhadap keaktifan dan hasil belajar IPA Biologi siswa kelas VII SMP Negeri 1 Berbah. Diperoleh kesimpulan penggunaan metode bermain peran(role playing) efektif digunakan dalam pembelajaran IPA. Peserta didik tampak lebih berminat dan antusias untuk melaksanakan belajar. Tingkat partisipasi peserta didik lebih baik serta kemampuan menggunakan pendapat dan saran juga menjadi lebih.Berdasarkan hal tersebut, maka peneliti tertarik untuk meneliti pengaruh metode pembelajaran bermain peran terhadap hasil belajar peserta didik dengan judul "Pengaruh metode pembelajaran bermain peran terhadap hasil 
belajar peserta didik kelas VII SMP Negeri 24 Bulukumba (studi pada materi pencemaran lingkungan).

Berdasarkan latar belakang yang telah diuraikan di atas, maka rumusan masalah dalam penelitian ini adalah sebagai berikut :

1. Seberapa tinggi tingkat hasil belajar peserta didik kelas VII SMP Negeri 24 Bulukumba pada materi pokok pencemaran lingkungan dengan menggunakan metode pembelajaran bermain peran?

2. Seberapa tinggi tingkat hasil belajar peserta didik kelas VII SMP Negeri 24 Bulukumba pada materi pokok pencemaran lingkungan dengan menggunakan metode ceramah?

3. Apakah ada pengaruh positif metode pembelajaran bermain peran terhadap hasil belajar IPA peserta didik kelas VII SMP Negeri 24 Bulukumba, pada materi pokok pencernaan lingkungan?

\section{METODE}

Jenis penelitian yang digunakan dalam penelitian ini ialah Quasy-eksperiment dengan mengunakan desain Non-equivalent posttest-only control group design. Penelitian dilaksanakan di SMP Negeri 24 Bulukumba. Populasi penelitian adalah seluruh peserta didik kelas VII SMP Negeri 24 Bulukumba tahun ajaran 2017/ 2018 yang terdiri dari lima kelas dengan jumlah keseluruhan 100 orang. Pemilihan sampel dilakukan dengan teknik random sampling dimana teknik penentuan sampel dilakukan secara acak maka dipilih dua kelas sampel yakni kelas VII1 sebagai kelas eksperimen dengan jumlah 20 orang dan kelas VII4 sebagai kelas kontrol dengan jumlah 19 orang.

Teknik pengumpulan data yang diperoleh melalui tes hasil belajar peserta didik. Tes hasil belajar tersebut dalam bentuk pilihan ganda yang disertai empat pilihan jawaban dengan keseluruhan berjumlah 20 disesuaikan dengan indikator dan skor untuk tiap butir soal adalah 1 untuk tiap jawaban yang benar dan o untuk tiap jawaban yang salah. Namun sebelum diujikan kepada peserta didik, soal ini terlebih dahulu divalidasi oleh guru yang bersangkutan. Setelah dinyatakan valid kemudian diujikan kepada peserta didik. Data yang diperoleh dianalisis menggunakan analisis statistik deskriptif dan analisis statistik inferensial

\section{HASIL DAN PEMBAHASAN}

Hasil analisis statistik deskriptif menunjukkan karakteristik hasil belajar peserta didik kelas eksperimen pada kelas VII.1 dan kelas control pada kelas VII.2 SMP Negeri 24 Bulukumba. Berikut ini disajikan rangkuman nilai hasil belajar peserta didik pada kelas eksperimen dan kelas kontrol.

\section{Tabel 1. Nilai Statistik Kelas Eksperimen dan Kelas Kontrol}

\begin{tabular}{lll}
\hline \multicolumn{1}{c}{ Statistik } & \multicolumn{1}{c}{$\begin{array}{c}\text { Kelas } \\
\text { Eksperimen }\end{array}$} & $\begin{array}{c}\text { Kelas } \\
\text { Kontrol }\end{array}$ \\
\hline Jumlah sampel & 20 & 19 \\
Nilai tertinggi & 90 & 85 \\
Nilai terendah & 52 & 40 \\
Nilai rata-rata & 75,50 & 68,16 \\
Standar deviasi & 12,55 & 16,19 \\
Varians & 157,50 & 262,11 \\
\hline
\end{tabular}

Tabel 1. di atas dapat dilihat nilai hasil belajar peserta didik pada materi pencemaran lingkungan untuk kelas eksperimen dan kelas kontrol. Pada kelas eksperimen nilai tertingginya 90 dan nilai terendahnya 52, sedangkan pada kelas kontrol nilai tertingginya 85 dan nilai terendahnya 40. Selain itu, pada kelas eksperimen terdapat nilai rata-ratanya 75,50 yang berada pada kategori 
tinggi standar deviasi 12,55 dan varians-nya 157,50 dan untuk kelas kontrol nilai rata-ratanya 68,16 yang berada pada kategori tinggi standar deviasi 16,19 dan varians-nya 262,11.

Perbandingan hasil belajar peserta didik pada kelas eksperimen dan kelas kontrol dapat dilihat pada Tabel 2.

Tabel 2. Perbandingan Hasil Belajar Peserta Didik

\begin{tabular}{llll}
\hline \multicolumn{1}{c}{ Interval } & $\begin{array}{c}\text { Kelas } \\
\text { Eksperimen }\end{array}$ & $\begin{array}{c}\text { Kelas } \\
\text { Kontrol }\end{array}$ & \multicolumn{1}{c}{ Kategori } \\
\hline $85 \leq \chi \leq 100$ & 7 & 7 & Sangat tinggi \\
$70 \leq \chi<85$ & 8 & 5 & Tinggi \\
$55 \leq \chi<70$ & 3 & 2 & Sedang \\
$35 \leq \chi<55$ & 2 & 5 & Rendah \\
$0 \leq \chi<35$ & 0 & 0 & Sangat rendah \\
\hline \multicolumn{5}{c}{ Jumlah } & 27 & 27 \\
\hline
\end{tabular}

Tabel 2 di atas menunjukkan bahwa peserta didik pada kelas eksperimen yang termasuk kategori sangat tinggi berjumlah 7 orang, kategori tinggi berjumlah 8 orang, kategori sedang berjumlah 3 orang, kategori rendah berjumlah 2 orang. Pada kelas kontrol yang termasuk kategori sangat tinggi berjumlah 7 orang, kategori tinggi berjumlah 5 orang, kategori sedang berjumlah 2 orang, dan kategori rendah berjumlah 5 orang.

Tabel 3. Persentase Pencapaian Tiap Indikator Kelas Eksperimen dan Kelas Kontrol

\begin{tabular}{|c|c|c|c|c|}
\hline \multirow[b]{2}{*}{ No } & \multirow[b]{2}{*}{ Indikator } & \multirow[b]{2}{*}{ Nomor soal } & \multicolumn{2}{|c|}{ Persentasi Pencapaian } \\
\hline & & & $\begin{array}{c}\text { Kelas } \\
\text { eksperimen }\end{array}$ & $\begin{array}{l}\text { Kelas } \\
\text { kontrol }\end{array}$ \\
\hline 1. & $\begin{array}{l}\text { Menjelaskan pengertian pencemaran } \\
\text { lingkungan }\end{array}$ & 1 & 90,0 & 78,9 \\
\hline 2. & $\begin{array}{l}\text { Mengidentifikasi faktor-faktor } \\
\text { penyebab terjadinya lingkungan }\end{array}$ & 2 dan 3 & 72,5 & 71,0 \\
\hline 3. & $\begin{array}{l}\text { Mendeskripsikan jenis-jenis } \\
\text { pencemaran lingkungan }\end{array}$ & $4,5,6$ & 76,5 & 64,7 \\
\hline 4. & $\begin{array}{l}\text { Menjelaskan pengertian pencemaran } \\
\text { tanah dan air }\end{array}$ & 7 & $80 \mathrm{mmmccv}, 0$ & 57,8 \\
\hline 5. & $\begin{array}{l}\text { Menjelaskan sumber-sumber } \\
\text { pencemaran tanah dan air }\end{array}$ & $8,9,10$ & $68, o n x^{i}$ & 66,0 \\
\hline 6. & $\begin{array}{l}\text { Menjelaskan dampak untuk mengatasi } \\
\text { pencemaran tanah dan air }\end{array}$ & $11,12,13,14,15$ & 74,0 & 70,5 \\
\hline 7. & $\begin{array}{l}\text { Menjelaskan pengertian pencemaran } \\
\text { udara }\end{array}$ & 16 & 90,0 & 68,4 \\
\hline 8. & $\begin{array}{l}\text { Menjelaskan sumber-sumber } \\
\text { pencemaran udara }\end{array}$ & 17 dan 18 & 80,0 & 63,1 \\
\hline 9. & $\begin{array}{l}\text { Menjelaskan dampak untuk mengatasi } \\
\text { pencemaran udara }\end{array}$ & 19 dan 20 & 67,5 & 63,1 \\
\hline & Rata- rata & & 77,6 & 67,5 \\
\hline
\end{tabular}

Tabel 3 terlihat bahwa terdapat perbedaan hasil persentase pencapaian indikator pemahaman konsep pada kelas eksperimen dan kelas kontrol. Pencapaian indikator yang paling 
tinggi pada kelas eksperimen ada dua yaitu pada indikator menjelaskan pengertian pencemaran lingkungan, dan menjelaskan pengertian pencemaran udara. Pencapaian indikator yang paling tinggi pada kelas kontrol yaitu menjelaskan pengertian pencemaran lingkungan. Pencapaian indikator yang paling rendah pada kelas eksperimen adalah pencapaian indikator menjelaskan dampak untuk mengatasi pencemaran udara, pencapaian indikator yang paling rendah pada kelas kontrol ada dua yaitu pencapaian indikator menjelaskan sumber-sumber pencemaran udara, dan menjelaskan dampak untuk mengatasi pencemaran udara. Persentase rata-rata pemahaman peserta didik pada sub materi pencemaran lingkungan pada kelas eksperimen adalah sebesar 77,6 $\%$ dan kelas kontrol sebesar $67,5 \%$. Adapun analisis statistik inferensial disajikan untuk pengujian hipotesis, dalam hal ini uji-t dengan taraf signifikansi $\alpha=0,05$. Syarat yang harus dipenuhi untuk pengujian hipotesis adalah data yang diperoleh berdistribusi normal dan mempunyai variansi yang homogen.

Untuk mengetahui apakah sampel yang diuji terdistribusi normal atau tidak maka dilakukan uji normalitas melalui uji Chi-kuadrat pada kelas eksperimen yang diajar menggunakan metode pembelajaran bermain peran dan kelas kontrol yang diajar menggunakan metode ceramah. Berdasarkan hasil analisis pengujian normalitas data dengan menggunakan uji Chi-Kuadrat, untuk kelas eksperimen diperoleh nilai $\chi_{\text {hitung }}^{2}=6,45$ sedangkan untuk kelas kontrol diperoleh nilai $\chi^{2}$ hitung $=6,67$. Untuk nilai $t_{\text {tabel }}$ pada taraf signifikan $\alpha=0,05$ dengan $\mathrm{dk}=3$ adalah 7,81 . Sehingga dapat dikatakan bahwa data nilai hasil belajar pada kelas eksperimen dan kelas kontrol berasal dari populasi berdistribusi normal dan syarat normalitas data dipenuhi.

Setelah kedua sampel dinyatakan berdistribusi normal, maka dilakukan uji homogenitas untuk mengetahui apakah data dalam penelitian ini memiliki varians yang sama (homogen) atau tidak (heterogen). Setelah dilakukan pengolahan data, maka untuk pengujian homogenitas varians diperoleh nilai $F_{\text {hitung }}$ sebesar 1,66 sedangkan nilai $F_{\text {tabel }}$ pada taraf signifikan 0,05 di peroleh $F_{\text {tabel }}$ 2,18 Data ini menunjukkan bahwa nilai $F_{\text {hitung }}$ lebih kecil dari pada nilai $F_{\text {tabel }}$ yaitu $F_{\text {hitung }}$ $=1,66<F_{\text {tabel }}=2,18$. Sehingga dapat dikatakan bahwa kedua data nilai hasil belajar tersebut berasal dari populasi yang homogen.

Berdasarkan pengujian prasyarat analisis data, data kelas eksperimen dan kelas kontrol dinyatakan berdistribusi normal dan homogen. Sehingga uji hipotesis dilakukan dengan uji-t. Adapun kriteria pengujiannya adalah jika $t_{\text {hitung }}>t_{\text {tabel }}$ pada taraf signifikan $\alpha=0,05$ maka $\mathrm{H}_{0}$ ditolak $\mathrm{H}_{\mathrm{a}}$ diterima dan sebaliknya jika $\mathrm{t}_{\text {hitung }}<\mathrm{t}_{\text {tabel }}$ maka maka $\mathrm{H}_{\mathrm{o}}$ diterima $\mathrm{H}_{\mathrm{a}}$ ditolak.

Hasil analisis data diperoleh nilai $t_{\text {hitung }}=1,75$ dan nilai $t_{\text {tabel }}$ pada taraf signifikan $(\alpha)=0,05$ dan $\mathrm{db}=37$, $\mathrm{t}_{\text {tabel }}(0,05)(37)=1,68$. Data ini menunjukkan bahwa nilai $t_{\text {hitung }}=1,75>t_{\text {tabel }}=1,68$ yang artinya hipotesis $\left(\mathrm{H}_{\circ}\right)$ ditolak dan hipotesis $\left(\mathrm{H}_{\mathrm{a}}\right)$ diterima. Sehingga dapat disimpulkan bahwa terdapat pengaruh positif metode pembelajaran bermain peran terhadap hasil belajar peserta didik kelas VII SMP Negeri 24 Bulukumba pada materi pencemaran lingkungan.

Hasil analisis statistik inferensial dalam uji hipotesis dengan menggunakan uji-t juga membuktikan bahwa thitung $>t_{\text {tabel }}$. Hal ini berarti $\mathrm{H}_{0}$ ditolak dan $\mathrm{H}_{\mathrm{a}}$ diterima. Dimana dapat dinyatakan bahwa terdapat pengaruh positif metode pembelajaran bermain peran terhadap hasil belajar peserta didik kelas VII SMP Negeri 24 Bulukumba pada materi pokok pencemaran lingkungan. Hal ini sesuai dengan penelitian sebelumnya yang dilakukan oleh Maftuhah (2008) yang mengemukakan bahwa pemberian metode pembelajaran bermain peran pada kelas eksperimen selama penelitian dilaksanakan membantu meningkatkan motivasi belajar peserta didik, minat peserta didik dan kemampuan peserta didik dalam menyerap pelajaran dan teknik ini perserta didik lebih tertarik perhatiannya akan permasalahan, mengembangkan diskusi yang hidup, karena mereka menghayati sendiri pembelajaran dan penonton tidak pasif, tetapi aktif mengamati dan mengajukan saran dan kritik. 
Penelitian yang dilakukan dapat membuktikan bahwa penggunaan metode pembelajaran bermain peran berpengaruh positif terhadap hasil belajar peserta didik. Hal tersebut dikarenakan sesuai prosedur pelaksanaan mulai dari observasi, pelaksanaan dan pengolahan data.

\section{KESIMPULAN}

Berdasarkan hasil penelitian dan pembahasan dapat disimpulkan sebagai berikut :

1. Hasil belajar peserta didik kelas VII SMP Negeri 24 Bulukumba dengan menerapkan metode pembelajaran bermain peran pada materi pokok pencemaran lingkungan berada pada kategori tinggi.

2. Hasil belajar peserta didik kelas VII SMP Negeri 24 Bulukumba dengan menerapkan metode ceramah pada materi pokok pencemaran lingkungan berada pada kategori sedang.

3. Terdapat pengaruh positif metode pembelajaran bermain peran terhadap hasil belajar peserta didik kelas VII SMP Negeri 24 Bulukumba pada materi pokok pencemaran lingkungan.

\section{DAFTAR PUSTAKA}

Agustini, T.H. 2012. Implementasi Metode Inquiry Untuk Meningkatkan Hasil Belajar Biologi. Jurnal Pendidikan IPA Indonesia JPII 1 (1) (2012) 16-20. Semarang: Prodi Pendidikan IPA FMIPA UNNES Semarang. http://journal.unnes.ac.id/index.php/jpii. di Akses Pada Tanggal 25 April 2015.

Anderson, L. \& Krathwhol, D. 2010. Kerangka Landasan Untuk Pembelajaran, Pengajaran, dan Asesmen. Yogyakarta: Pustaka Belajar

Hadija, S. 2010. Penerapan model pembelajaran bermain peran untuk meningkatkan hasil belajar IPA siswa kelas III SDN Randomayang. Jurnal Kreatif Tadulako Online Vol. 3 No 2, ISSN 2345614X. Mahasiswa Program Guru Dalam Jabatan Fakultas Keguruan dan Ilmu Pendidikan Universitas Tadulako.

Hamalik, O. 2008. Proses Belajar Mengajar. Jakarta: Bumi Aksara.

Kurrniasih, S. 2015. Ragam Pengembangan Model Pembelajaran. Kata Pena. Jakarta.

Maftuhah. 2008. Pengaruh Model Pembelajaran Bermain Peran (Role Playing) Terhadap Hasil Belajar Siswa Kelas XII SMA Dalam Konsep Substansi Genetika, Jakarta: Skrips Fakultas IImu Tarbiyah dan Keguruan UIN Syarif Hidayatullah Jakarta.

Sabri, A. 2007. Strategi Belajar Mengajar \& Mikro Teaching. Jakarta: PT Ciputat Press.

Sani, R.A. 2013. Inovasi Pembelajaran. Jakarta; Bumi Aksara.

Selviana, W. 2013. Pengaruh metode Role Playing terhadap keaktifan dan hasil belajar IPA Biologi siswa kelas VII Smp Negeri 1 Berbah. Skripsi Jurusan Pendidikan Biologi Fakultas Sains dan teknologi Universitas Islam Negeri Sunan Kalijaga Yokyakarta.

Siska,Yulia. 2011 Penerapan Metode Bermain Peran (Role Playing) dalam Meningkatkan Keterampilan Sosial dan Keterampilan Berbicara Anak Usia Dini. Diakses (06 Juli 2013). http://ejournal.upi.edufile4-yulia_siska-edit.pdf.

Siregar, E \& Nara, H.2010. Teori Belajar dan Pembelajaran.Jakarta ;Ghalia Indonesia.

Sukmadinata, N. 2007. Landasan psikologi proses pendidikan. Bandung : PT Remaja Rosdakarya.

Sumiati. 2009. Metode Pembelajaran. Bandung: CV Wacana Prima.

Tawil, M. \& Liliasari, 2014.Keterampilan-keterampilan sains dan implementasi dalam pembelajaran IPA, Badan penerbit universitas negeri makassar :makassar 


\section{Sitti Rahma Yunus}

Dosen Prodi Pendidikan IPA Universitas Negeri Makassar, aktif meneliti di bidang pembelajaran IPA dan fisika, dapat dihubungi melalui pos-el: sitti.rahma.yunus@unm.ac.id

\section{Sudarto}

Dosen, aktif melakukan penelitian pada bidang pendidikan IPA, dapat dihubungi melalui ponsel:

\section{Risman Adrianto}

Alumni Prodi Pendidikan IPA Universitas Negeri Makassar 